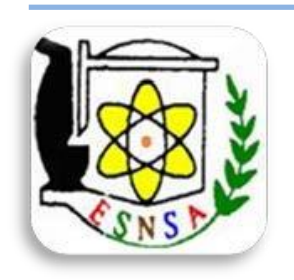

Arab Journal of Nuclear Sciences and Applications

ISSN 1110-0451

Web site: ainsa.journals.ekb.eg

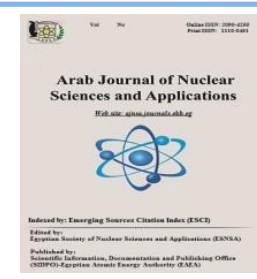

(ESNSA)

\title{
Effect of Aging on the Immune Status and Trace Elements
}

\author{
Dalia R. Ibrahim* and Michael I. Michael \\ Biological Applications Department, Nuclear Research Center, Atomic Energy Authority, Cairo, Egypt
}

\begin{abstract}
Received $20^{\text {th }}$ Jan. 2020 Accepted $20^{\text {th }}$ Feb. 2020

Aging is usually accompanied by immunosenescence. Trace elements such as zinc (Zn), iron (Fe), and copper $(\mathrm{Cu})$ are essential for effective immune function. This study aims at assessing the aging effect on the levels of zinc, iron and copper, estimating the association between their serum concentrations and markers of the immune system including immunoglobulins G, immunoglobulins M, immunoglobulins A, immunoglobulins E, interleukin-4, interleukin-5 and interferon-gamma. The study also, aims at evaluating the interaction between the tested immunological parameters and trace elements. Eighty volunteers participated in this study, aged from 30 to 65 years. They were divided into two equal groups according to their age; the middle-aged group, aged from 30 to 45, and the older group, aged from 50 to 65 years. Zinc, iron, copper and the immune parameters namely, immunoglobulins G, immunoglobulins $M$, immunoglobulins A, immunoglobulins $\mathbf{E}$, interleukin-4, interleukin-5 and interferon- $\gamma$ were assayed in serum. The results showed significant increases of all the tested immunological parameters except for IL-4 and IgM in the older group compared to the middle-aged group, while for the trace elements concentrations, a trend towards increased values was observed in the older group. Age affects both humoral and cellular immunity, although it has a greater influence on humoral immunity. In the present study, trace elements were found to have a relation to both types of immunity especially in the middle age.
\end{abstract}

Keywords: Aging, Immunoglobulin, Interferon- $\gamma$, Interleukin, Trace Element

\section{Introduction}

Aging is a complex biological phenomenon that is associated with changes in the immune system, increasing the susceptibility to acute and chronic diseases and the risk of physical and cognitive disability $[1,2]$. The decline in protective immune responses in aging is termed "immunosenescence" [3]. Aging is also associated with low levels of chronic inflammation in the absence of overt infection, termed "inflammaging" [4]. It is suggested that immunosenescence and inflammaging are risk factors for most aging diseases such as infections, chronic inflammatory diseases and autoimmune disorders. This state of nonspecific chronic inflammation is accompanied by increased blood concentrations of inflammatory mediators such as C-reactive protein (CRP), interleukin-6 (IL-6), interleukin-8 (IL-18) and tumor-necrosis factor- $\alpha(\mathrm{TNF}-\alpha)$ [5] .

Aging is also accompanied by changes in the numbers and functions of T-lymphocytes [6]. It causes an increase in the number of memory and effector cells in both $\mathrm{CD} 4^{+}$and $\mathrm{CD}^{+}$subsets [7] and an increase in proinflammatory cytokines such as IFN- $\gamma$, IL- 2 , and TNF- $\alpha$, while IL- 4 , IL- 6 and IL-10 increase only with the increase in the number of memory $\mathrm{CD}^{+}$cells. On the other hand, there is a gradual decrease in the functional responses of $\mathrm{T}$ cells, which may be due to alterations in cytokine production and response [6]. In aging, there is a shift in the cytokines production towards the Th2-type profile (IL-4 and IL-10) rather than the Th1-type profile (IL-2 and IFN- $\gamma$ ) [8].

Trace elements are required in optimal levels for effective immune functions [9]. Overt trace 
elements deficiencies can affect the immune system and predispose individuals to infections [10-12]. Both cell-mediated and humoral immunity, and the release of proinflammatory cytokines depend on the presence of adequate amounts of trace elements such as zinc, iron and copper. Aging is associated with increasing the risk of trace elements deficiencies due to reduced food intakes and age-related metabolic and physiologic changes.

Zinc is one of the most relevant nutritional factors in aging as it affects the immune response. It induces the development, differentiation and activation of T-lymphocytes [13, 14] and mediates the Th1 mediated immune response [13]. Zinc promotes the cytotoxic activity of natural killer (NK) cells $[9,13,15]$ and the phagocytic activity of macrophages [16]. It induces the production of cytokines such as IL-2, IL-6 and TNF- $\alpha[17,18]$ and may be involved in the production of IFN- $\gamma$ [19]. Zinc has also a role in the production of antibodies, especially $\operatorname{IgE}[20,21]$.

Copper is another trace element that is essential for the maintenance of immune function. It has a role in cellular immunity, as it induces the differentiation and proliferation of T-cells and NK activity. Copper is important for the production of IL-2 and its deficiency reduces IL-2 expression in $\mathrm{T}$ cells [22]. Copper also has a role in humoral immunity, as it induces the production of antibodies [22-23].

There is a cross-regulatory interaction between iron homeostasis and immune function. Iron plays a role in the differentiation and proliferation of $\mathrm{T}$ lymphocytes [9, 22]. It is important for neutrophils function [9] and may play a role in IFN- $\gamma$ production. Decreased phagocytosis by polymorphonuclear cells and alteration of the secretion of Th1 and Th2 cytokines have been reported in iron deficient patients and mice respectively $[24,25]$.

The aim of the current study is to assess the aging effect on the levels of zinc, iron and copper, estimate the association between their serum concentrations and markers of the immune system including immunoglobulins $\mathrm{G}$, immunoglobulins M, immunoglobulins A, immunoglobulins $\mathrm{E}$, interleukin-4, interleukin-5 and interferon-gamma and to evaluate the interaction between the tested immunological parameters and trace elements in order to clarify the importance of their use as supplements in infections.

\section{Material and Methods \\ Participants}

This study was performed on eighty volunteers, 38 males and 42 females, age ranged from 30 to 65 years. They were divided into two equal groups according to their age; the middle-aged group, aged from 30 to 45, 18 males and 22 females and the older group, aged from 50 to 65, 20 males and 20 females. All participants were subjected to full medical history taking and complete clinical examination. Patients suffering from acute or chronic infections, chronic inflammatory diseases, cancers, autoimmune diseases or chronic metabolic diseases were excluded. The volunteers did not take any nutritional supplements. An informed consent was obtained from each individual participant included in the study.

\section{Estimation of trace elements and immune parameters}

Blood samples were withdrawn from volunteers; after clotting, samples were centrifuged for $15 \mathrm{~min}$. at $2000 \mathrm{x} \mathrm{g}$ and the sera were frozen at $-80{ }^{\circ} \mathrm{C}$ and analyzed for quantitative determination of trace elements and immune parameters. The concentrations of $\mathrm{Fe}, \mathrm{Zn}$ and $\mathrm{Cu}$ in serum were assayed utilizing atomic absorption using (Sens AA- GBC scientific equipment) according to AOAC 1990 (Official methods of analysis $15^{\text {th }} \mathrm{Ed}$ in association of official analytical chemists Washington, DC, USA, 1990). The immunoglobulins (IgG, IgM and $\operatorname{IgA}$ ) were estimated utilizing simple radial immunodiffusion. IgG was determined using 3-plate, Combi-plate, by FAR srl (Verona-Italy). IgM and IgA were estimated using Diffu-plate by Biocientifica S.A. (Argentina). The concentrations of IgE, IL-4 and IL-5 were evaluated using ELISA technique according to the manufacturer's protocol. IgE was determined using Biocheck (USA) kit, IL-4 was evaluated using Ray Biotech (Inc. 3607 Parkway Lane, Norcross GA 30092) kit and IL-5 was estimated using Boster biological technology LTD. (USA) kit. The ELISA tests were read by Stat Fax Reader. IFN- $\gamma$ was evaluated by radioimmunoassay using Bio-source Europe S.A. (Belgium) Kit.

\section{Compliance and ethical standards}

All procedures performed involving human participants were in accordance with the ethical standards of the institutional and national research committee and with the 1964 Helsinki declaration 
and its later amendments or comparable ethical standards. An informed consent was obtained from each individual participant included in the study.

\section{Statistical analysis}

Data were analyzed using the statistical package for social sciences (SPSS, version 20 for windows, Chicago, USA). Results were expressed as means \pm standard deviation (SD). Statistical differences between the groups were performed using Paired Student Test. $\mathrm{P}<0.01$ was considered statistically significant. Correlation analysis between trace elements concentrations and immune parameters were conducted using Pearson correlation test.

\section{Results}

Effect of aging on $\operatorname{IgE}, \operatorname{IgA}, \operatorname{Ig} G, \operatorname{Ig} M, I L-4, I L-5$, IFN- $\gamma, \mathrm{Fe}, \mathrm{Cu}$ and $\mathrm{Zn}$

Table (1) summarizes the tested parameters in the middle-aged group and the older group. The olderage group showed high significant increases $(\mathrm{p}<0.01)$ in IgE, IgA, IgG, IL-5 and IFN-gamma, a high significant decrease in IgM and insignificant changes in IL-4, compared to the middle-aged group. As for the trace elements $\mathrm{Fe}, \mathrm{Cu}$ and $\mathrm{Zn}$, there was a trend towards increased values in the older group though insignificant.

Correlation between trace elements concentrations and immune parameters in the middle-aged group

Table (2) illustrates the correlation between the trace elements $(\mathrm{Fe}, \mathrm{Cu}$ and $\mathrm{Zn}$ ) concentrations and the immune parameters in the middle-aged group. There was a positive significant correlation between $\mathrm{Fe}$ and each of IgE, IgG, IL-4, IL-5 and IFN- $\gamma \quad(\mathrm{P}<0.01)$, while there was a negative significant correlation with IgA in the same group. Regarding copper, there was a positive significant correlation with $\operatorname{IgM}(\mathrm{P}<0.01)$ and a negative significant correlation with $\operatorname{IgE}(\mathrm{P}<0.01)$. Zinc in the same group showed a positive significant correlation with $\operatorname{IgE}(\mathrm{P}<0.05)$ and $\operatorname{IFN}-\gamma(\mathrm{P}<0.01)$ and a negative significant correlation with $\operatorname{IgA}$, IgM, IL-5 $(\mathrm{P}<0.01)$ and IL-4 $(\mathrm{P}<0.05)$.
Table (1): Effect of aging on IgE, IgA, IgG, IgM, IL-4, IL5 , IFN- $\gamma, \mathrm{Fe}, \mathrm{Cu}$ and $\mathrm{Zn}$

\begin{tabular}{lcc}
\hline Parameters & $\begin{array}{c}\text { Middle-aged } \\
\text { group } \\
(\text { mean } \pm \text { SD) }\end{array}$ & $\begin{array}{c}\text { Older group } \\
\text { (mean } \pm \text { SD) }\end{array}$ \\
\hline $\mathrm{IgE}(\mathrm{IU} / \mathrm{ml})$ & $326 \pm 14.45$ & $531.4 \pm 30.6 * *$ \\
$\mathrm{IgA}(\mathrm{mg} / \mathrm{dl})$ & $153.3 \pm 13.09$ & $247.2 \pm 12.82 * *$ \\
$\mathrm{IgG}(\mathrm{mg} / \mathrm{dl})$ & $1520.7 \pm 32.7$ & $1859.2 \pm 30.7 * *$ \\
$\mathrm{IgM}(\mathrm{mg} / \mathrm{dl})$ & $160 \pm 6.07$ & $122.7 \pm 6.86 * *$ \\
$\mathrm{IL}-4(\mathrm{pg} / \mathrm{ml})$ & $0.17 \pm 0.09$ & $0.21 \pm 0.02$ \\
$\mathrm{IL}-5(\mathrm{pg} / \mathrm{ml})$ & $5.6 \pm 1.19$ & $32.29 \pm 1.6 * *$ \\
$\mathrm{IFN}-\gamma(\mathrm{IU} / \mathrm{ml})$ & $1.14 \pm 0.16$ & $3.7 \pm 0.41 * *$ \\
$\mathrm{Fe}(\mathrm{mg} / \mathrm{L})$ & $1.9 \pm 0.37$ & $1.95 \pm 0.28$ \\
$\mathrm{Cu}(\mathrm{mg} / \mathrm{L})$ & $0.74 \pm 0.06$ & $0.91 \pm 0.07$ \\
$\mathrm{Zn}(\mathrm{mg} / \mathrm{L})$ & $1.23 \pm 0.11$ & $1.71 \pm 0.27$ \\
$\mathrm{IgE}(\mathrm{IU} / \mathrm{ml})$ & $326 \pm 14.45$ & $531.4 \pm 30.6 * *$ \\
\hline
\end{tabular}

Statistically significant from group 1: $* * \mathrm{p}<0.01$.The data is expressed as mean $\pm \mathrm{SD}$.

Correlation between trace elements concentrations and immune parameters levels in the older group

Table (3) shows the correlation between the trace elements ( $\mathrm{Fe}, \mathrm{Cu}$ and $\mathrm{Zn}$ ) concentrations and the immune parameters in the older group. There was a positive significant correlation between $\mathrm{Fe}$ and both $\mathrm{IgE}$ and IL-5 $(\mathrm{P}<0.05)$, while there was a negative significant correlation with IFN- $\gamma(\mathrm{P}<$ 0.05). In the same group, $\mathrm{Cu}$ showed a positive significant correlation with $\operatorname{IgE}$ and $\operatorname{IgM}(\mathrm{P}<0.05)$. Meanwhile, $\mathrm{Zn}$ showed a positive significant correlation with $\operatorname{IgM}(\mathrm{P}<0.01)$, IL-5 and IFN- $\gamma$ $(\mathrm{P}<0.5)$.

\section{Discussion}

Immunosenescence decreases the capacity of the immune system through reduction in the efficiency of humoral immunity and alteration in the helper/suppressor $\mathrm{T}$ cell ratio [26]. Immune cells, similar to all other types of cells, require an adequate supply of trace elements for maintaining

Table (2): Correlation between trace elements concentrations and immune parameters levels in the middle-aged group

\begin{tabular}{cccccccc}
\hline & $\operatorname{IgE}$ & $\operatorname{IgA}$ & $\operatorname{IgG}$ & $\operatorname{IgM}$ & $\operatorname{IL}-4$ & IL-5 & IFN- $\gamma$ \\
\hline $\mathrm{Fe}$ & $0.688^{* *}$ & $-0.716^{* *}$ & $0.799^{* *}$ & 0.214 & $0.982^{* *}$ & $0.958^{* *}$ & $0.616^{* *}$ \\
$\mathrm{Cu}$ & $-0.838^{* *}$ & -0.031 & 0.094 & $0.747 * *$ & 0.221 & 0.168 & -0.265 \\
$\mathrm{Zn}$ & $0.559^{*}$ & $-0.865^{* *}$ & -0.053 & $-0.763 * *$ & $-0.504 *$ & $-0.840 * *$ & $0.699 * *$ \\
\hline
\end{tabular}

Values of Correlation Coefficients are significant at the levels of $\mathrm{P}<0.05 *$ and $\mathrm{P}<0.01 * *$. 
Table (3): Correlation between trace elements concentrations and immune parameters levels in the older group

\begin{tabular}{cccccccc}
\hline & IgE & IgA & IgG & IgM & IL-4 & IL-5 & IFN- $\gamma$ \\
\hline $\mathrm{Fe}$ & $0.440^{*}$ & 0.097 & 0.012 & -0.214 & -0.395 & $0.433^{*}$ & $-0.450^{*}$ \\
$\mathrm{Cu}$ & $0.488^{*}$ & 0.115 & -0.282 & $0.553^{*}$ & -0.098 & 0.018 & 0.518 \\
$\mathrm{Zn}$ & -0.060 & 0.038 & 0.187 & $0.743^{* *}$ & -0.097 & $0.635^{*}$ & $0.628^{*}$ \\
\hline
\end{tabular}

Values of Correlation Coefficients are significant at the levels of $\mathrm{P}<0.05 *$ and $\mathrm{P}<0.01 * *$

the activity of a number of enzymes directly participating in the defense processes, and the synthesis and secretion of cytokines. Another important function of trace elements is that they are involved in the structure and function of metalloproteins that participate in energy production and cell protection against highly toxic reactive oxygen species [27].

$\operatorname{IgM}$ is the first antibody appearing in the primary immune response to antigen [28]; a low primary immune response is usually associated with aging in both the naïve $\mathrm{T}$ and $\mathrm{B}$ cells, while the memory cells are relatively maintained. In the secondary immune response, the memory cells are activated and produce antigen-specific IgG [28]. Therefore, the decrease in IgM and the increase in IgG are expected in old age. This agrees with Castellao Tavares et al. [29], who reported that there was a significant decrease in IgM and an increase in IgG in elderly compared with young people. The increase in $\operatorname{IgG}, \operatorname{IgA}$ and $\operatorname{IgE}$ may also contribute to the chronic low-level inflammatory status, infectious diseases and/ or this increase may be considered a compensatory mechanism to the low efficiency of the circulating antibodies. There were no significant differences in the $\mathrm{Fe}, \mathrm{Cu}$ or $\mathrm{Zn}$ levels between the two examined groups; this may be due to the nutritional awareness of the participants or to the notion that their levels may not be affected by age.

The positive significant correlation between $\mathrm{Fe}$ and $\mathrm{IgE}$ in both groups, and between $\mathrm{Fe}$ and $\mathrm{IgG}$ and its negative correlation with $\operatorname{IgA}$ in the middleaged group agreed with Yapi et al. [30], who worked on children aged from 5 to 15 and reported that iron deficiency was associated with reduced IgG levels, although immunoglobulins $\mathrm{A}$ and $\mathrm{M}$ remained stable. On the other hand, Sadeghian et al. found that there were insignificant differences in the levels of $\operatorname{IgG}, \operatorname{IgA}$ and $\operatorname{IgM}$ in adult females suffering from mild iron deficiency anaemia, and significant decrease in IgM in moderate to severe iron deficiency anaemia, compared to the control [31]. This may be attributed to the role of iron in the proliferation and maturation of lymphocytes. Reduced iron levels would thus lead to the decrease of $B$ lymphocyte production and reduction in immunoglobulins synthesis.

The positive significant correlation between $\mathrm{Fe}$ and IL-5 in both groups and between $\mathrm{Fe}$ and both IL-4 and IFN- $\gamma$ in the middle-aged group agreed, to some extent, with Kuvibidila and Warrier [25] who demonstrated that dietary iron limitation is associated with reduced serum levels of IFN- $\gamma$, IL12 and IL-10. These results suggest that the balance between pro and anti- inflammatory cytokines is altered by the iron status. This imbalance may have an effect on innate and cell mediated immunity. The negative significant correlation between $\mathrm{Fe}$ and IFN- $\gamma$ in the older group is consistent with the findings of some authors [32] who reported that both IFN- $\gamma$ and IL-4 lead to $\mathrm{Fe}$ retention in circulating monocytes and macrophages and reduction of circulating $\mathrm{Fe}$ concentration. This may be a defense mechanism of the body to limit the availability of iron for extracellular pathogens, especially in the elderly, who are at an increased risk of susceptibility to infectious diseases.

Hodkinson et al. [33] reported an inverse association between serum $\mathrm{Zn}$ concentration and age. These results disagreed with the present study, which may be due to the nutritional awareness of the old-aged individuals in the present study, or due to the different age groups studied. Previous studies have shown that marginal $\mathrm{Zn}$ status in elderly individuals has a relation to a weakened immunity [34]. This is obvious in the current results as there was a significant correlation between $\mathrm{Zn}$ and most of the tested immunological parameters, especially in the middle-aged group. The negative correlation between $\mathrm{Zn}$ and both $\operatorname{IgA}$ and $\mathrm{IgM}$ in the middle-aged group and its positive correlation with $\operatorname{IgM}$ in the older group may be due to the effect of $\mathrm{Zn}$ on the antibodies production $[20,21]$. It was reported that aging affects B cell numbers and antibodies production. $\mathrm{B}$ cell numbers decline with age, however 
immunoglobulins do not decrease, on the contrary, there was an increase of $\operatorname{IgA}$ and several IgG subclasses [35], which agreed with the findings of the present work.

Th1/Th2 balance is affected by zinc. In case of zinc deficiency, the ratio of Th1 and Th2 cells is disturbed in favor of Th2 [36] and the production of Th1 cytokines, in particular IFN- $\gamma$ and IL-2, is reduced, meanwhile, the Th2 cytokines, IL-4, IL-6 and IL-10 are not affected, resulting in a shift toward Th2 cytokines [37]. This agreed with the obtained results, where there was a positive significant correlation between $\mathrm{Zn}$ and IFN- $\gamma$ in both groups and a negative significant correlation between $\mathrm{Zn}$ and both IL-4 and IL-5 in the middleaged group. The positive correlation between $\mathrm{Zn}$ and IFN- $\gamma$ in both groups suggests that $\mathrm{Zn}$ is an essential micronutrient that can function as an antiinflammatory agent [13]. Zinc affects the inflammatory markers; previous studies showed that $\mathrm{Zn}$ deficiency increases the concentration of inflammatory cytokines $[20,38]$ and that $\mathrm{Zn}$ supplementation has favorable effects in reducing inflammatory markers in obese individuals [39]. Zinc status is the main factor affecting inflammatory markers rather than the plasma zinc concentrations through its influence on monocytes and macrophages that produce these inflammatory markers, and thus intracellular zinc concentration, such as the lymphocyte zinc concentration, is a better indicator of zinc status [20].

In the present study, and contrary to $\mathrm{Zn}, \mathrm{Cu}$ showed a negative significant correlation with $\operatorname{IgE}$ and a positive significant correlation with $\operatorname{IgM}$ in the middle-aged group, while it showed a positive significant correlation with $\operatorname{IgE}$ in the older group. This confirms the findings of the work of Malavolta et al. [40] who stated that increased plasma copper and/or decreased plasma $\mathrm{Zn}$ is associated with changes of inflammatory parameters or the presence of age-related diseases. This agreed with the current results where the serum $\mathrm{Cu}$ concentration in the older group is a little higher than that in the middle-aged one. In young adult age, these alterations are normally transient, but in advancing age, the balance between $\mathrm{Cu}$ and $\mathrm{Zn}$ may permanently be affected due to pathogen accumulation, immunosenescence, and the chronic low-level inflammatory status [41].

\section{Conclusion}

Age affects both humoral and cellular immunity, although it has a greater influence on humoral immunity. In the present study, trace elements were found to have a relation to both types of immunity, especially in the middle age.

Trace elements deficiency may have a widespread effect on all components of the immune system, although there is still a need for further studies to assess the nature and concentration of micronutrients necessary to influence immunity; yet the supply of these trace elements in infectious diseases may be beneficial. Further studies on elder age (up to 80 years) are also recommended to increase the confirmation of the aging effect on the immune system and trace elements.

\section{References}

1. Barnes, P.J. (2015) Mechanisms of Development of Multimorbidity in the Elderly, Eur Respir J., 45, 790-806.

2. Da Costa, J.P., Vitorino, R., Silva, G.M., Vogel, C., Duarte, A.C. and Rocha- Santos, T. (2016) A Synopsis on Aging-Theories, Mechanisms and Future Prospects, Ageing Res Rev., 29, 90-112.

3. Aw, D., Silva, A.B. and Palmer, D.B. (2007) Immunosenescence: Emerging Challenges for an Ageing Population, Immunology, 120, 435446.

4. Cevenini, E., Monti, D. and Franceschi, C. (2013) Inflamm-Ageing, Curr Opin Clin Nutr Metab Care, 18,14-20.

5. Scheller, J., Chalaris, A., Schmidt-Arras, D. and Rose-John, S. (2011) The Pro- and AntiInflammatory Properties of the Cytokine Interleukin-6, Biochim Biophys Acta, 1813, 878-888.

6. Ponnappan, S. and Ponnappan, U. (2011) Aging and Immune Function: Molecular Mechanisms to Interventions, Antioxid Redox Signal, 14, 1551-1585.

7. Sansoni, P., Vescovini, R., Fagnoni, F., Biasini, C., Zanni, F., Zanlari, L., et al. (2008) The Immune System in Extreme Longevity, Exp Gerontol, 43, 61-65.

8. Rink, L., Cakman, I. and Kirchner, H. (1998) Altered Cytokine Production in the Elderly. Mech Ageing Dev, 102, 199-209.

9. Maggini, S., Pierre, A. and Calder, P.C. (2018) Immune Function and Micronutrient Requirements Change over the Life Course, Nutrients, 10, 1531. 
10. Alpert, P. (2017) The Role of Vitamins and Minerals on the Immune System, Home Health Care Manag Pract., 29, 199-202.

11. Calder, P. (2013) Conference on 'Transforming the Nutrition Landscape in Africa'. Plenary Session 1: Feeding the Immune System", Proc Nutr Soc., 72, 299 309.

12. Milner, J. and Beck, M. (2012) Micronutrients, Immunology and Inflammation. The Impact of Obesity on the Immune Response to Infection, Proc Nutr Soc., 71, 298-306.

13. Maggini, S., Beveridge, S., Sorbara, J.P. and Senatore, G. (2008) Feeding the Immune System: The Role of Micronutrients in Restoring Resistance to Infections, $C A B$ Rev., 3, 1-21.

14. Wintergerst, E., Maggini, S. and Hornig, D. (2006) Immune-Enhancing role of Vitamin C and Zinc and Effect on Clinical Conditions, Ann Nutr Metab., 50, 85-94.

15. Wu, D., Lewis, E.D., Pae, M. and Meydani, S.N. (2019) Nutritional Modulation of Immune Function: Analysis of Evidence, Mechanisms, and Clinical Relevance, Front Immunol, 9, 3160.

16. Gao, H., Dai, W., Zhao, L., Min, J. and Wang, F. (2018) The Role of Zinc and Zinc Homeostasis in Macrophage Function, $J$ Immunol Res., 2018, 6872621.

17. Foster, M. and Samman, S. (2012) Zinc and Regulation of Inflammatory Cytokines: Implications for Cardiometabolic Disease, Nutrients, 4, 676-694.

18. Wessels, I. and Rink, L. (2019) Micronutrients in Autoimmune Diseases: Possible Therapeutic Benefits of Zinc and Vitamin D, J Nutr Biochem, 77, 108240.

19. Haryanto, B., Suksmasari, T., Wintergerst, E. and Maggini, S. (2015) Multivitamin Supplementation Supports Immune Function and Ameliorates Conditions Triggered by Reduced Air Quality, Vitam Miner, 4, 1-15.

20. Shankar, A.H. and Prasad, A.S. (1998) Zinc and Immune Function: The Biological Basis of Altered Resistance to Infection, Am J Clin Nutr., 68, 447s-463s.

21. Ibs, K.H. and Rink, L.(2003) Zinc-Altered Immune Function, $J$ Nutr., 133, 1452S-1456S.

22. Saeed, F., Nadeem, M., Ahmed, R., Nadeem, M., Arshad, M. and Ullah, A. (2016) Studying the Impact of Nutritional Immunology Underlying the Modulation of Immune

Arab J. Nucl. Sci. \& Applic. Vol. 54, No. 1 (2021)
Responses by Nutritional Compounds-A review, Food Agric Immunol., 27, 205-229.

23. Maggini, S., Wintergerst, E., Beveridge, S. and Hornig, D. (2007) Selected Vitamins and Trace Elements Support Immune Function by Strengthening Epithelial Barriers and Cellular and Humoral Immune Responses, $\mathrm{Br} \mathrm{J}$ Nutr, 98, S29-S35.

24. Bergmann, M., Hertzel, S., Pinchasi, R., Straussberg, R., Djaldetti, M. and Bessler, H. (2005) Phagocytic Capacity and Apoptosis of Peripheral Blood Cells from Patients with Iron Deficiency Anemia, Biomed Phamacother, 59, 307-311.

25. Kuvibidila, S.R. and Warrier, R.P. (2004) Differential Effects of Iron Deficiency and Underfeeding on Serum Levels of Interleukin10, Interleukin-12 p40, and Interferon-Gamma in Mice, Cytokine, 26,73-81.

26. Uciechowski, P., Kahmann, L., Plumakers, B., Malavolta, M., Mocchegiani, E., Dedoussis, G., et al. (2008) TH1 and TH2 Cell Polarization Increases with Aging and is Modulated by Zinc Supplementation, Exp Gerontol., 43, 493-498.

27. Munoz, C., Rios, E., Olivos, J., Brunser, O. and Olivares, M. (2007) Iron, Copper and Immunocompetence, Br J Nutr., 98(1), 24-28.

28. Alberts, B., Johnson, A., Lewis, J., Walter, P., Raff, M. and Roberts, K. (2002) "Chapter 24" The Adaptive Immune System, Molecular Biology of the cell ( $4^{\text {th }}$ ed.) New York. Garland Science.

29. Castellao Tavares, S.M.Q.M., Bravo Junior, W.L., and Alves Leite, J.L. (2015) Analyze the Levels of Immunoglobulins $\operatorname{IgG}$ and $\operatorname{IgM}$ in Elderly and Youngs, Int $J$ Immunol Immunother., $\mathbf{1}, 1$.

30. Yapi, H.F., Ahiboh, H., Yayo, E., Edjeme, A., Attoungbre-Hauhouot, M.L., Allico, J.D., et al. (2009) Immune, Inflammatory, and Nutritional Protein Profile in Children with Iron Deficiency in, Sante, 19(1), 25-28.

31. Sadeghian, M.A., Keramati, M.R., Ayatollahi, H., Manavifar, L., Enaiati, H. and Mahmoudi, M. (2010) Serum Immunoglobulins in Patients with Iron Deficiency Anemia, Indian $J$ Hematol Blood Transfus., 26(2), 45-48.

32. Ludwiczek, S., Aigner, E., Theurl, I. and Weiss, G. (2003) Cytokine-Mediated Regulation of Iron Transport In Human Monocytic Cells, Blood, 101, 4148-4154. 
33. Hodkinson, C.F., Kelly, M., Alexander, H.D., Bradbury, I., Robson, P.J., Bonham, M.P., et al. (2007) Effect of Zinc Supplementation on the Immune Status of Healthy Older Individuals Aged 55-70 Years: The Zenith Study, J Gerontol A Biol Sci Med Sci., 62(6), 598-608.

34. Borden, J.D. (2004) Influence of Zinc on Immunity in the Elderly, $J$ Nutr Health Aging, 8(1): 48-54.

35. Paganelli, R., Quinti, I., Fagiolo, U., Cossarizza, A., Ortolani, C., Guerra, E., et al. (1992) Changes in Circulating B Cells and Immunoglobulin Classes and Subclasses in a Healthy Aged Population, Clin Exp Immunol., 90, 351-354.

36. Prasad, A.S. (2000) Effects of Zinc Deficiency on Th1 and Th2 Cytokine Shifts, J Infect Dis., 182, S62-S68.

37. Beck, F.W.J., Prasad, A.S., Kaplan, J., Fitzgerald, J.T. and Brewer, G.J. (1997) Changes in Cytokine Production and $\mathrm{T}$ Cell Subpopulations in Experimentally Induced Zinc-Deficient Humans, Am J Physiol., 272, E1002-1007.

38. Prasad, A.S., Beck, F.W., Bao, B., Fitzgerald, J.T., Snell, D.C., Steinberg, J.D., et al. (2007)
Zinc Supplementation Decreases Incidence of Infections in the Elderly: Effect of Zinc in Generation of Cytokines and Oxidative Stress, Am J Clin Nutr., 85, 837-844.

39. Khorsandi, H., Nikpayam, O., Yousefi, R., Parandoosh, M., Hosseinzadeh, N., Saidpour, A., et al. (2019) Zinc Supplementation Improves Body Weight Management, Inflammatory Biomarkers And Insulin Resistance in Individuals with Obesity: a Randomized, Placebo-Controlled, DoubleBlind Trial, Diabetol Metab Syndr., 11,101.

40. Malavolta, M., Giacconi, R., Piacenza, F., Santarelli, L., Ciprianom C., Costarelli, L., et al. (2010) Plasma Copper/Zinc Ratio: an Inflammatory/Nutritional Biomarker as Predictor of All-Cause Mortality in Elderly Population, Biogerontology, 11, 309-319

41. Mocchegiani, E., Basso, A., Giacconi, R., Piacenza, F., Costarelli, L., Pierpaoli, S., et al. (2010) Diet (Zinc)-Gene Interaction Related to Inflammatory/Immune Response in Ageing: Possible Link with Frailty Syndrome, Biogerontology, 11, 589-595. 